\title{
Towards an innovative olive oil value chain: Options for inclusive development in South-Eastern Tunisia
}

\author{
Mondher Fetoul*, Boubaker DhehibI ${ }^{\star \star}$, Aymen Frija***, \\ Abderrahman SghaleR ${ }^{\star \star \star \star}$, Shinan N Kassam ${ }^{\star \star \star \star *}$, Aden Aw- \\ Hassan $^{* \star}$, Mohamed Arbi Abdeladhim****** , Mongl Sghaier*
}

DOI: $10.30682 / \mathrm{nm} 2003 \mathrm{a}$

JEL codes: N15, O13, O31

\begin{abstract}
The objective of this paper is to analyse the olive oil value chain $(O V C)$ in the Governorate of Medenine (south-east of Tunisia) and the relationships between its main operators for an effective involvement and better performance and resilience of olive sector. Based on semi structured interviews and participatory multi-stakeholders'workshops, OVC has been analysed and described. MACTOR approach has been applied to establish linkages among chain operators and activities in a partnership approach. Innovative interventions were proposed to strengthen farmers' organizations to increase profitability of OVC. Empirical findings suggest that public-private-civil society partnerships are essential for the development of pro-poor approaches for uncovering technological and institutional innovations which may involve more inclusive olive oil value chains. The underpinnings of our argument will be of interest and value to both development practitioners and the research community engaged within Tunisia, and the wider region more generally, on initiatives aimed at fostering effective, inclusive and contextually relevant processes for agricultural innovation.
\end{abstract}

Keywords: Value chain, Olive oil, Social innovation, MACTOR analysis, Inclusive development, Propoor, Tunisia.

\section{Introduction}

The challenges related to risk and opportunity for marginal olive oil producers in Tunisian arid regions should be highlighted, to promote the sector and resolve problems related to social injustice and rural food insecurity. In fact, the vagaries of weather, within an environment of climate change, constrain stability in the volume of olive oil produced. Land fragmentation, stemming from inheritance and land ownership norms, leads to a lack of bargaining power, and when coupled with a lack of stability in output, relatively lower farm gate prices. House-

\footnotetext{
* Laboratory of Economy and Rural Societies, Arid Regions Institute (IRA) of Medenine, Tunisia.

** Resilient Agricultural Livelihood Systems Program, International Center for Agricultural Research in the Dry Areas (ICARDA), Amman, Jordan.

*** Resilient Agricultural Livelihood Systems Program, International Center for Agricultural Research in the Dry Areas (ICARDA), Tunis, Tunisia.

**** Laboratory of Eremology and Combating Desertification, Arid Region Institute (IRA) of Medenine, Tunisia.

***** Caritas Sweitzerland, Dushanbe, Tajikistan.

****** Higher School of Agriculture of Mograne, Zaghouan, Tunisia.
}

Corresponding author: b.dhehibi@cgiar.org 
hold risk minimization strategies which rely on the storage of olive oil as insurance potentially undermine collective efforts for marketing and quality assurance.

Furthermore, despite inordinate sums of public and private funds spent annually on agricultural research in Tunisia, rural poverty remains intractable, agricultural productivity growth has been uneven, and issues related to rural social injustice and food insecurity continue to persist within the region (Karray and Abichou, 2007).

The low productivity of olive sector in Tunisian arid regions is due to several factors. More than $80 \%$ of the olive grove is beyond the optimum age ( 70 years), and therefore their productivity is declining. Irrigation infrastructure is largely absent, further lowering productivity. Input costs tend to be higher due to the increase of labour, coupled with the absence of skilled labourers. Another crucial factor causing poor competitiveness of olive sector is the large number of small farms that represents obstacle for mechanization of agriculture sector and the introducing of innovative ideas. The majority of exports olive oils, at national and regional level (more then 90\%) are in the form of bulk generic oil that is subsequently packaged in Italy as well as some other countries. Bulk generic olive oil cannot garner price premiums (Karray and Kanoun, 2013); thus, the potential of what is a superior quality product is wasted. This situation is aggravated by the lack of operators and negotiators with a long-term business strategy.

At the institutional level, many rural institutions within the region are largely parastatal in nature and continue to function as such. These include agricultural associations, farmer unions and cooperatives, through which a myriad of subsidies are disseminated for both productive and consumptive uses. In addition, centralized production planning for State defined strategic crops is often undertaken and coordinated with the public agricultural extension system through these parastatal institutions. The distinction between State priorities and household agricultural production decisions has, therefore, been blurred.

The rapidly changing context of agriculture has resulted in a transformation of the way knowledge is generated and applied. Agricultural development is increasingly taking place in a globalized setting which implies that domestic markets alone no longer define demand. Agricultural systems are increasingly complex and knowledge from other domains is increasingly more important. Affected by technical, social, economic, political and environmental issues, the range of issues that must therefore be addressed to foster agricultural development is vast and it is nigh impossible to achieve adequate foresight.

Hence, what is required is a different approach towards the generation and application of agricultural knowledge; traditional approaches to agricultural research and extension are no longer sufficient to enable agricultural innovation and development to take place. In fact, over the years, perspectives on the role of agricultural research for development have shifted considerably, moving from linear Transfer-of-Technology (ToT) models in the 1960s to 'Farmer First' and Farming Systems Research approaches in the 1980s and 1990s. Participatory approaches that came into vogue in the 1990s contributed to technology generation and adoption that further brought in economic, market driven value chain thinking into agricultural research and extension. However, neither participatory approaches nor value chains addressed the organizational and institutional factors required for technological changes to sustain (Gildemacher and Wongtschowski, 2015).

Thus, development and adoption of contextually relevant technologies and innovations are more likely to be successful when there is 1) a process of continuous learning, jointly undertaken by research organizations, farmers, marketing agents, donors, NGO's, financial service providers, policy makers, and relevant civil society; and 2) a framework of development policy which promotes marginalized olive oil producing rural communities' inclusivity and economic returns equitability.

The value chain approach is increasingly recognized as a promising approach to meet not only the requirements of economic development, job creation and inclusive growth but also the new challenges of social and environmental development (Stamm and Von Drachen- 
fels, 2011). This approach needs to address organizational and institutional factors to ensure inclusive development, in keeping within the spirit of uncovering more effective and profitable processes for innovation.

The objective of this paper is to analyse the OVC in the Governorate of Medenine, south-east of Tunisia, and the relationships between its main operators for an effective involvement and better performance and resilience of olive sector. To reach this objective of inclusive development of the OVC, this paper discusses the outcomes of 1) a participatory process of learning which include olive oil producers in southern Tunisia, rural organisations and institutions and civil society organizations, by the mean of several multi-stakeholders' workshops; 2) the relationships between these stakeholders in relation to their challenges and objectives by the mean of MACTOR method. This latter is used to determine the motivations, conflicts and potential strategic alliances among the involved operators in OVC in order to suggest better ways of supporting social innovation in marginalized rural areas in south-eastern Tunisia; and 3) an innovative value chain based on partnership approach with main operators in order to strengthen social capital and farmers' organizations to increase OVC profitability.

\section{Methodological framework}

\subsection{Value chain approach, inclusive development and social innovation}

Several definitions of the value chain from international literature are available. Porter (1985) defined the value chain as a powerful tool for disaggregating a company into its strategically relevant activities in order to focus on the sources of competitive advantage, that is, the specific activities that result in higher prices or lower costs. According to Aube (1994), the value chain is the assembly including actors involved in the production, distribution, processing and consumption of a given product or group of products and the multiple and complex interrelations between them.

This work is in the framework of inclusive development which is based on a pro-poor approach that equally values and incorporates the contributions of all stakeholders. It promotes transparency and accountability and enhances olive sector governance cooperation outcomes through collaboration between civil society, governments and private sector (Oxfam, 2018). This inclusive development of pro-poor value chains should be accompanied by social innovation which is a process that empowers the economic, social, and environmental conditions of disadvantaged groups. An innovation is 'social' because it involves a collective learning process between a range of different actors with different kinds of knowledge, rather than an individual one led, for example, by science or a single inventor (Howaldt et al. 2010; European Commission, 2013).

In this paper we refer to an innovation platform as "a diversity of interdependent stakeholders who jointly attempt to positively change the way they operate by trying out new practices" (Nederlof et al. 2011). Homann-Kee Tui et al. (2013) states that an innovation platform is "a group of individuals (who often represent organizations) with different backgrounds and interests: farmers, traders, food processors, researchers, government officials, etc. coming together to diagnose problems, identify opportunities, and find ways to achieve their goals. They may design and implement activities as a platform, or individually...".

This work can then help to address systemic constraints shared by multiple stakeholders operating in the OVC and places great emphasis on understanding the nature of relationships between them, and the attitudes and practices that shape those relationships. Relationships promote interaction and interaction promotes learning and innovation (World Bank, 2007) in order to bring new products, new processes, and new forms of organization into economic use, together with the institutions and policies that affect behaviour and performance" (Triomphe and Rajalahti, 2013; Swaans et al., 2014).

\subsection{Contextual analysis: the case study}

The study was conducted in the Governorate of Medenine (Figure 1) located in the south-east of Tunisia. This Governorate covers an area of $8588 \mathrm{~km}^{2}(5.2 \%$ of the area of Tunisia) and has 
Figure 1 - Localization of Medenine Governorate.

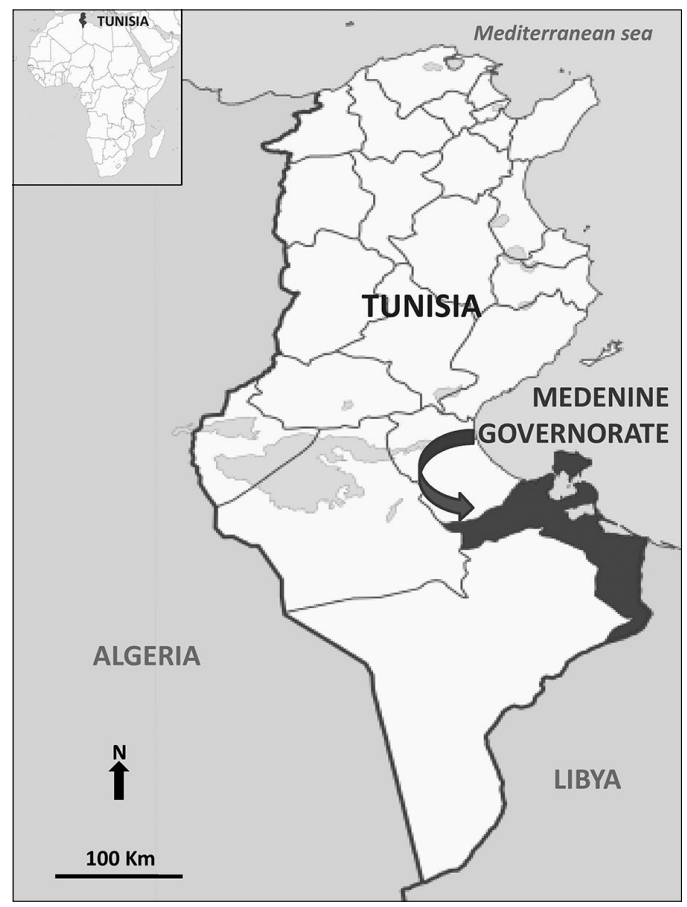

Source: own elaboration, 2019.

a population of 432.503 inhabitants (INS, 2015) belonging to nine delegations (administrative units). It belongs to the arid bioclimatic stage with a rainfall varying between 100 and $200 \mathrm{~mm}$ per year.

Olive production is a key agricultural activity within Medenine which is the fifth largest olive growing area in Tunisia, covering 190,000 hectares with about 4.5 million olive trees (equal to $82.5 \%$ of the total cultivable area of the Governorate, and $6.5 \%$ of the nation's total production). A number of olive varieties produced within the Governorate are known for their unique attributes in terms of taste. The olive oil production is around 22760 tons per year (ODS, 2017).

\subsection{Data collection}

Different types of data were collected over a period of five years (2013-2018), aiming at enhancing the analytical and empirical work. Part of this data was quantitative, while another part was rather based on expert knowledge and multi-stakeholders focus groups and discussion. So, the methodological framework was based on a set of integrated approaches.

In addition to the literature review, seven multi-stakeholder workshops were co-organized successively since 2013 in different locations (at the Arid Regions Institute (IRA), the Regional administration for agriculture development (CRDA) and at local NGO's offices). These focus group discussions involved the main stakeholder groups involved in the OVC in Medenine Governorate. Our team already had established partnership with these stakeholders which have facilitated the organization of these workshops.

Participants in focus group discussions represented the main public institutions and administrations supporting the OVC development such as the CRDA (Ministry of Agriculture), the South development office (ODS) and the Agricultural Investment Promotion Agency (APIA). They represent also representatives of the nongovernmental and community-based organisations (NGOs and CBOs) such as the Tunisian union of agriculture and fishing (UTAP), the agriculture development groups (GDA), the mutual societies of agricultural services (SMSA) and the water use organization (GIC). Agricultural research institutions were also involved in these workshops (IRA and the Olive Institute (IO)), with the National Olive Oil Office (ONH).

Direct operators of the OVC have also participated to the focus group discussions. These include service providers, farmers (olive growers), industrial processors, traders and consumers. The gender aspect was considered in the selection of target participants (Table 1).

The conducted workshops were moderated by the research team with the contribution of other main stakeholders (such as CRDA and NGOs). Group discussions were fruitful and focused on 1) analysing the major challenges and opportunities of the olive oil sector; 2) identifying the selected commodity; 3) identifying the main operators of the value chain and their strategies; 4) characterizing and evaluating the existing relationships and interactions among these actors, and identifying prospects for their cooperation for more effective OVC; 5) organizing data collection and field surveys; and 6) promoting the institutional set-up for innovative value chain 
Table 1 - Multi-stakeholder workshops description.

\begin{tabular}{|c|c|c|}
\hline Workshops & Participants & Major outcomes \\
\hline $\begin{array}{l}\text { December } \\
14^{\text {th }}, 2013\end{array}$ & $\begin{array}{l}43 \text { participants ( } 8 \text { women and } \\
35 \text { men) representing NGOs, } \\
\text { CBOs and administration }\end{array}$ & $\begin{array}{l}\text { Identification of a range of local products and commodities } \\
\text { with higher priorities to be promoted throughout the high } \\
\text { value chain cluster. } \\
\text { Highlighting the interest and the value of cooperation } \\
\text { between research, development actors, civil society, local } \\
\text { population, and donors. }\end{array}$ \\
\hline $\begin{array}{l}\text { June } 3-4^{\text {th }} \\
2014\end{array}$ & $\begin{array}{l}32 \text { participants ( } 13 \text { women and } \\
19 \text { men) representing NGOs, } \\
\text { CBOs and administration }\end{array}$ & $\begin{array}{l}\text { Confirmation of the priority given to Olive oil as the most } \\
\text { important production in the area. } \\
\text { Identification of the major challenges, potential objectives } \\
\text { and opportunities of the olive oil sector in the region. }\end{array}$ \\
\hline $\begin{array}{l}\text { October } 1^{\text {st }} \\
2014\end{array}$ & $\begin{array}{l}17 \text { participants representing } \\
\text { NGOs, CBOs and } \\
\text { administration }\end{array}$ & $\begin{array}{l}\text { Listing of different stakeholders directly and indirectly } \\
\text { involved in OVC. } \\
\text { Fine tuned methodological approach for extensive primary } \\
\text { data collection from the field. }\end{array}$ \\
\hline $\begin{array}{l}\text { March } 17^{\text {th }}, \\
2015\end{array}$ & $\begin{array}{l}19 \text { participants representing the } \\
\text { main stakeholders involved in } \\
\text { the implementation of the OVC }\end{array}$ & $\begin{array}{l}\text { Discussing and evaluating the existing relationships } \\
\text { and interactions among stakeholders in relation to } \\
\text { OVC (stakeholder/stakeholder matrix of influences and } \\
\text { dependencies). } \\
\text { Identification of stakeholders' perceptions and strategies for } \\
\text { effective OVC. }\end{array}$ \\
\hline $\begin{array}{l}\text { April } 20^{\text {th }}, \\
2016\end{array}$ & $\begin{array}{l}19 \text { participants representing the } \\
\text { main stakeholders involved in } \\
\text { the implementation of the OVC }\end{array}$ & $\begin{array}{l}\text { Discussing and validation of MACTOR results. } \\
\text { Comparative assessment of stakeholders' strategies related } \\
\text { to challenges and potential objectives of OVC (stakeholders/ } \\
\text { objectives matrix). } \\
\text { Analyzing challenges and opportunities of the olive oil } \\
\text { sector via a better stakeholder's cooperation. }\end{array}$ \\
\hline $\begin{array}{l}\text { May } 10^{\text {st }} \\
2017\end{array}$ & $\begin{array}{l}21 \text { participants representing the } \\
\text { main stakeholders involved in } \\
\text { the implementation of the OVC }\end{array}$ & $\begin{array}{l}\text { Promoting the institutional set-up of an innovation platform } \\
\text { based on the high value-added produced commodities } \\
\text { (olive). }\end{array}$ \\
\hline $\begin{array}{l}\text { June } 25^{\text {th }}, \\
2018\end{array}$ & $\begin{array}{l}20 \text { participants representing the } \\
\text { main stakeholders involved in } \\
\text { the implementation of the OVC }\end{array}$ & $\begin{array}{l}\text { An innovative OVC was conceived and agreed to be } \\
\text { implemented throughout a partnership approach. }\end{array}$ \\
\hline
\end{tabular}

Source: Own elaboration based on focus groups discussions (2019).

platform based on higher added value of the produced commodities (olive). All details about these workshops and major derived outcomes are presented in the following table (Table 1).

These investigations were coupled with field surveys based on specific complementary questionnaires, which have been conducted with 62 farmers (olive growers) in the region in order to characterize the existing olive farming systems from productivity and quality perspectives. Considered farms were selected based on farm- ing system typology previously carried out by the research team (Jaouad and Gaillard, 2017; Sghaier, 2017) in the region. The identification of the surveyed farmers was undertaken with the collaboration of community leaders and technical services.

Interviews were conducted by the research team during the period from $1^{\text {st }}$ November to $31^{\text {st }}$ December 2018. The questionnaire was organized in six main sections: Household demographic information, agricultural systems, water 
management practices, farm economic analysis, social networks and relationships with the other stakeholders involved in OVC, and community-identified problems assessment. Each interview lasted on average $30 \mathrm{~min}$. The data collected have been coded and cleaned using Excel and data analysis was carried out using SPSS software.

\subsection{MACTOR method}

In order to analyse the interaction between the main operators of the OVC, MACTOR (Method of ACTors, Objectives, strength Reports) tool and software were used. This method proposes a stakeholder analysis approach that allows taking into account the richness and complexity of relationships between operators. By defining the position of each operator for the defined objectives and the relations of power between them, the method allows analyzing their eventual alliances and expected future behavior. It contributes finally to the formulation of key and strategic recommendations to enhance the effectiveness of OVC (Godet and Durance, 2011).

The previous assessment of focus group discussions allows us to identify two main entry data to MACTOR: the matrix of "stakeholder/ stakeholder" influences and dependencies, and the matrix of "stakeholders/objectives".

MACTOR can provide firstly an "influences and dependencies plan", using the stakeholder/stakeholder matrix (called "MIDI matrix"). This latter matrix is a two-dimensional plan where each axis represents influence (I) versus dependence (D). It represents the positioning of the operators according to their degree of direct influences and dependencies on each other. Five levels of relationships among operators are classified according to the degree of influence/ dependence (Godet, 1991):

0 : The operator has little or no influence on "operator x".

1: The operator is capable of jeopardizing the management processes of "operator $\mathrm{x}$ " to some extent in time and space.

2: The operator is capable of jeopardizing the success of projects undertaken by "operator $\mathrm{x}$ ".
3: The operator is capable of preventing "operator $\mathrm{x}$ " from carrying out his mission.

4: The operator is capable of jeopardizing the existence of "operator $\mathrm{x}$ " or is vital to his existence.

This plan is subdivided into four parts showing four categories of stakeholders (dominant, relay, autonomous and dominated stakeholders) (Godet, 1991; Elmsalmi and Hachicha, 2014).

MACTOR can also provide the "histogram of relation powers", which is based also on MIDI matrix, taking in account another information related to the indirect influences that a operator $\mathrm{i}$ has on an operator $\mathrm{j}$ (MIDI)ij and also of an operator i on himself which is channeled through a relay operator and that we call feedback (MIDI)ii.

Godet (1979) states that power relations are calculated using Ii, Di and Matrix of Direct and Indirect Influences (MIDI)ij using the following formula (Equation 1):

$$
\mathrm{R}_{\mathrm{i}}=\frac{\mathrm{I}_{\mathrm{i}}-\mathrm{MIDI}_{\mathrm{ii}}}{\sum \mathrm{I}_{\mathrm{i}}} \frac{\mathrm{I}_{\mathrm{i}}}{\mathrm{I}_{\mathrm{i}}+\mathrm{D}_{\mathrm{i}}}
$$

(Equation 1)

Thus, MACTOR generates a scalar that determines the relative strength of each operator considering its influence and its direct dependence. The more the scalar is important, the higher the operator is in a strong position (Elmsalmi and Hachicha, 2014). The balance of power of an operator will be higher if his influence is high, his dependence weak and his feedback weak (Godet and Durance, 2011). An operator can also have both a very strong influence, a very strong dependence and at the same time an important feedback: his balance of power will then be very weak. However, an operator with a medium influence and a very weak dependence and feedback will have an important balance of power.

MACTOR elaborates also the "Correspondence map of stakeholders/objectives". The objective of this map is to adjust the relationships of each operator with respect to specific objectives and to identify potential alliances and conflicts. It offers a second reading of the conflictual (sum of disagreements) or consensual (sum of agreements) objectives and shows the objectives which gather the maximum of consensus between stake- 
holders, but also identify the stakeholders most involved in the achievement or non-achievement of objectives. The most the stakeholders and objectives are near each other (with respect to the horizontal and vertical axis) the more stakeholders are positioned similarly to those objectives (Elmsalmi and Hachicha, 2014).

In this step, the strategic stakes and associated goals and position of each operator according to each objective (Convergences and Divergences) have been identified based on the stakeholders/ objective's matrix (called "MAO Matrix"). With this matrix, current attitudes of each operator with respect to a given objective is indicated with agreement $(+1)$, disagreement $(-1)$ or neutrality (0). To identify the alliances and possible conflicts, the method clearly shows every pair of stakeholders and the number of objectives they are in agreement or disagreement. A positive or negative sign is given as follows: $(+)$ (Positive) if the selected operator is in favor of the objective, (-) (Negative) if the selected operator is not in favor of the objective. Five levels are classified according to the operator's position regarding the objective as follow:
0 : The objective is not consistent for the operator.

1: The objective is vital to the operator's operational processes (management, etc.).

2: The objective is vital to the operator's plans.

3: The objective is vital to the operator's missions.

4: The objective is vital to the operator's existence.

\section{Results}

\subsection{Key operators and map of the olive oil value chain in Medenine}

Based on literature review, field surveys and focus group discussions, the main operators of the OVC in Medenine Governorate are identified and mapping (Figure 2). These operators contribute either directly or indirectly to the implementation of the olive sector in the study area. Direct operators are those who ensured the production, storage, packaging, processing, marketing and consumption; thus, they are ser-

Figure 2 - Olive oil value chain in Medenine Governorate.

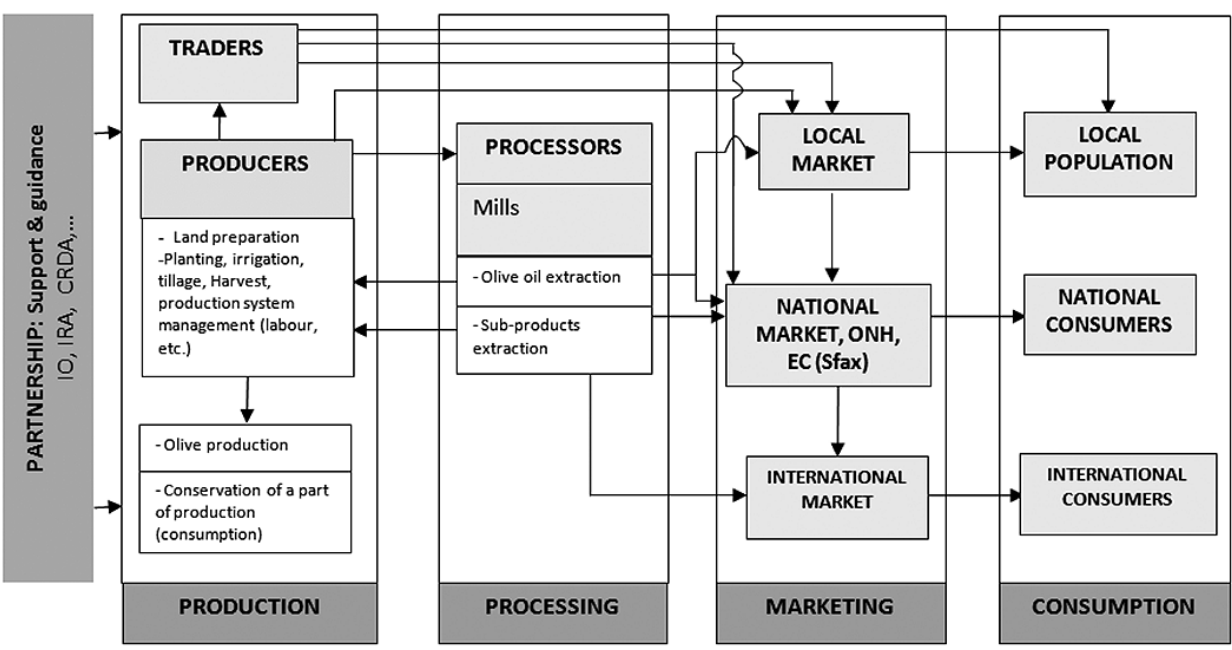

Legend 
vice providers, farmers (olive growers), industrial processors, traders and consumers. Indirect operators are those who have contributed to administrative and institutional support and supervision of the OVC implementation, such as administrations, nongovernmental organisations (NGOs), community-based organisations (CBOs), agricultural development programmes and research institutions.

\section{Services providers (SP)}

OVC in Medenine benefits from diverse services and facilities provided by different contributors mainly: 1) input suppliers; 2) olive and worker transporters; 3) tractors owners who provide tillage and transport; 4) specialized workers who maintain the olive trees; 5) charcoal producers who buy the wood from the olive growers and produce coal, which is used as the main source of heating; and 6) breeders who buy timber and pomace from olive growers for animal feeding.

\section{Olive growers (OG)}

Several actions are carried out by farmers (plantation, tillage, irrigation, harvest and sale of olives and olive oil). The majority of farmers prefer to grind their olive for their own account. This direct operator is very dependant to climate variability and climate change, but also to natural resources, especially the scarcity of water is the main characteristic of Tunisia arid regions.

\section{Processors (PR)}

In Medenine, the processing operation is ensured by 156 olive oil mills with a capacity of extraction that reaches 2,800 tons per day (ODS, 2017). The main roles of this direct operator are processing of olive, sale of olive oil and olive pomace.

\section{Traders}

$\mathrm{OVC}$ in the study area is dominated by the informal circuit. Indeed, a part of the chain goes outside the conventional circuits, from where most farms sell their olive production to local and regional private traders (TR) who in turn sell the products to national traders such as exportation companies (EC), located mostly in Sfax region. Processors sell also the olive oil to local and regional consumers, to $\mathrm{EC}$, and to $\mathrm{ONH}$. In fact, most of the olive oil produced is bought by $\mathrm{ONH}$ and other private companies.

\section{Consumers (CONS)}

Olives and olive oil are consumed either by the local population or destined for regional, national and international markets where quality remains a determining criterion for consumption. Exports of olive oil are largely organized and guaranteed by $\mathrm{ONH}$, but also by the private sector mainly to European, American and Canadian markets.

\section{Support operators}

OVC in Medenine mobilizes a set of support operators who intervene indirectly and provide administrative and institutional supports. There are four main public institutions and administrations supporting the OVC, which are the CRDA whose role is agriculture sector development, the ODS with its main role of planning, the development projects (DP) and the APIA in charge of promoting agriculture private investment. There are also the nongovernmental and community-based organisations represented by the UTAP who assures a syndic role and gives its support to the local associations (GDA, SMSA and GIC). These local associations are formal structures involved in agriculture and play specifically a central role in the participatory management of olive sector. The agricultural research institutions (IRA, IO) play also an important supporting role in OVC. They are carrying out research aiming to improve productivity and conservation of olives and olive oil and giving support to all operators of the OVC (capacity building, training, extension, etc.).

\subsection{Challenges and potential objectives of the OVC in Medenine Governorate}

The previous assessment of focus group discussions allows us to identify nine potential objectives of the OVC, with regards to the challenges of the olive sector in Tunisian arid regions (Table 2). These challenges and objectives are related mainly to the quality of olives and olive oil, the productivity of olive sector and 
Table 2 - List of main challenges and objectives of the OVC in Medenine Governorate.

\begin{tabular}{|l|l|l|}
\hline \multicolumn{1}{|c|}{ Challenges } & \multicolumn{1}{|c|}{ Objectives } & Abbreviation \\
\hline $\begin{array}{l}\text { Storage and transfer period that are often in poor conditions, } \\
\text { delay in processing olives, lack of encouragement and } \\
\text { subsidies to produce better quality }\end{array}$ & $\begin{array}{l}\text { Improve the quality of } \\
\text { olive oil }\end{array}$ & QUALT \\
\hline $\begin{array}{l}\text { Production instability and vulnerability of the sector to } \\
\text { climate change and variability }\end{array}$ & $\begin{array}{l}\text { Sustainability of olive } \\
\text { sector }\end{array}$ & SUST \\
\hline $\begin{array}{l}\text { Climate constraints, land fragmentation, water resources } \\
\text { scarcity, low public and private investments in productive } \\
\text { infrastructure, low crushing capacity of mills }\end{array}$ & $\begin{array}{l}\text { Improving the productivity } \\
\text { of olive sector }\end{array}$ & PROD \\
\hline Problems in cooperation between operators & $\begin{array}{l}\text { Inclusive development of } \\
\text { olive oil value chain }\end{array}$ & INCDEV \\
\hline Problems in olive sector organization & Organization of olive sector & ORG \\
\hline Decrease of selling prices, low margin profits & Improve the income & INCOM \\
\hline Non qualification of service providers and NGO's & $\begin{array}{l}\text { Improve extension and } \\
\text { capacity building }\end{array}$ & EXTENS \\
\hline Traditional collecting method, need for social innovation & $\begin{array}{l}\text { Social innovation in olive } \\
\text { value chain }\end{array}$ & INNOV \\
\hline $\begin{array}{l}\text { Complexity of olive sector (administration, credits, } \\
\text { transactions, etc.) }\end{array}$ & $\begin{array}{l}\text { Improve facilities in olive } \\
\text { value chain }\end{array}$ & FACILT \\
\hline
\end{tabular}

Source: own elaboration based on focus group discussions results (2019).

the management, governance and sustainability of the olive value chains.

In the Tunisian arid zones, olive and olive oil yields remain low and largely due to climate constraints, land fragmentation, water resources scarcity, low public and private investments in productive infrastructure (Ahmed et al., 2008; Fleskens et al., 2005; Hachani et al., 2015; Karray and Abichou, 2007; Sghaier et al., 2012).

In addition, many olive groves are aging and irrigation infrastructure is largely absent, further lowering both productivity and quality. The harvested olives are usually in very advanced stages of maturation with traditional collecting method to which is added storage and transfer period that are often in poor conditions. These conditions cause deterioration of the olive oil quality and decrease of selling prices. Furthermore, the lack of encouragement and subsidies to produce better quality does not help to the improvement of production techniques or marketing.

Furthermore, the processing industry in Tunisia generally suffers from regional disparity. In fact, northern Tunisia and Sfax region dominate the Tunisian olive sector. In our study area, it is noted that some mills have a low crushing capacity and a delay in processing olives, and this can affect the quality of crushed oil, but also the selling price (Karray and Kanoun, 2013). In addition, olive mills have not developed a more sophisticated packaging or treatment of the extracted oils. So, there is no effort on product differentiation for specific markets niche (such as the flavoured oil development or packaged).

The profit margins distribution in the olive value chains in these regions reveals that the most profitable operator is the traders (Yahya, 2017). In fact, the informal circuit obliges producers (olive growers) to sell their production at lower prices with a low margin profit (Karray and Kanoun, 2013).

\subsection{Relationships and mutual influences between OVC operators (MACTOR results)}

This section is providing, from MACTOR tool, the results of the analysis of relationships and mutual influences between the already identified operators described in the previous sections.

\section{Influences and dependencies}

Findings show that there are dominant stakeholders who have a strong influence on the others without being strongly influenced (ex. Lo- 
Figure 3 - Plan of influences and dependencies between OVC operators in Medenine.

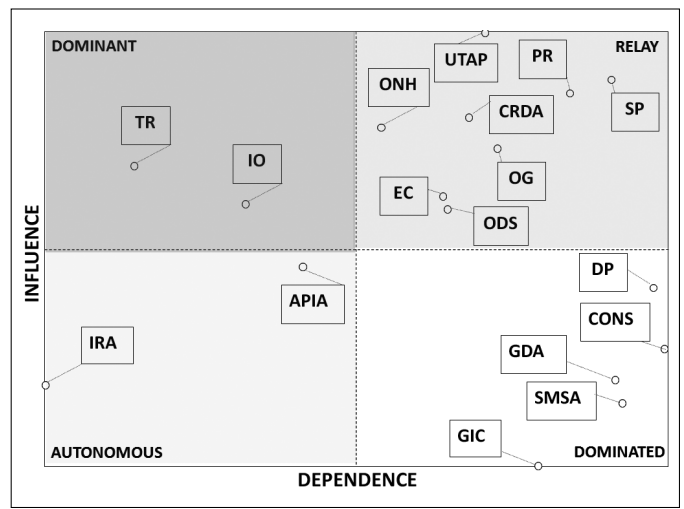

Source: own elaboration from MACTOR analysis, 2019.

cal and regional private traders (TR) and Olive institute (IO)) (Figure 3). The results confirm that OVC in the study area is dominated by the informal circuit. The IO is an important research operator responsible for undertaking all research, study and experimentation activities in order to develop and promote the olive sector. This institution is under the authority of the Ministry of Agriculture.

Most of direct operators of the OVC are relay stakeholders (SP, OG, PR, ONH, EC) because they have a strong influence but are strongly dependent, because they are responsible of all the operations in the OVC and they are dependent to socioeconomic, political and environmental conditions. Three support operators are also relay, the CRDA and ODS as the main public administration supporting the OVC and UTAP who assures an important syndic role and gives its support to the local associations in the region.

The histograms of relation powers (Figure 4) confirm the favourable balance of power or the strong power of these dominant and relay stakeholders because they have a Ri superior than 1 .

The GIC, as water use organisation, has the lowest power since its $\mathrm{Ri}=0.3$, and this is due to the rainfed character of the olive oil production systems, but also to degraded financial conditions as well as for the other NGO's (GDA and SMSA). Finding show also that local and regional private traders (TR), although they are dominant in term of influence, they have a weak balance of power compared to $\mathrm{OG}, \mathrm{SP}$ and $\mathrm{ONH}$ (ONH is the main operator in charge of collect and export of Tunisian olive oil). This weakness in relation power should be considered to reduce the role of TR in OVC and the unbalanced profit margin distribution in the OVC.

There are also dominated stakeholders in the OVC, who have a weak influence and are strongly influenced (ex. Consumers, DP, GDA, SMSA, GIC). The consumers are influenced by the quantity, quality and prices of olive and olive oil. The NGO's (GDA, GIC, SMSA) and Development projects (DP) are influenced by financial conditions, political and institutional changes and appreciation of local population.

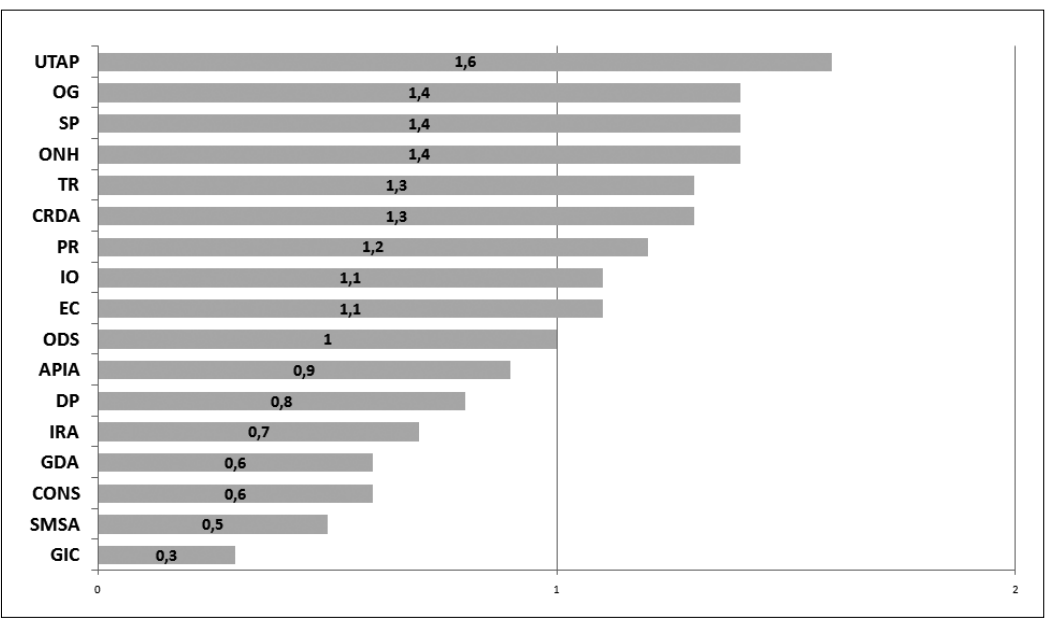

Figure 4 - Histogram of power relations of OVC operators in Medenine. Source: own elaboration from MACTOR analysis, 2019. 
Figure 5 - Correspondence map of stakeholders/objectives (OVC in Medenine).

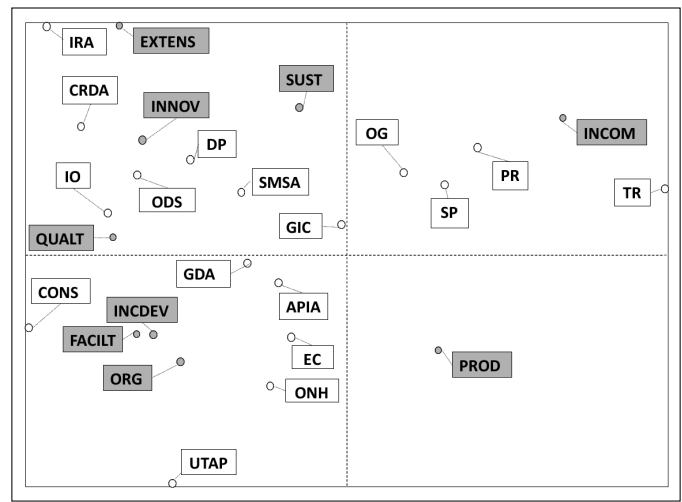

Source: own elaboration from MACTOR analysis, 2019.

In order to reach stability and effectiveness of the OVC in Medenine, the relationships among operators have to evolve and dominated operators shall fade or grow in importance.

Importance of the objectives according to operators' positions and strategies: Potential alliances and conflicts

As mentioned in Figure 5, the most involved operators in the OVC are GDA (NGO's) and consumers, which are concerned by three objectives: inclusive development of the OVC (INCDEV), organization of the olive sector (ORG) and improve facilities in olive value chain (FACILT). Although this involvement, these operators are completely dominated and have a non favorable balance of power to achieve these three objectives.

Besides, the UTAP is not effectively involved although its favorable balance of power, and it is only concerned by improving the "Organization" of olive sector. The consumers are not effectively concerned by income and this confirms the fact that the majority of farmers prefer to grind their olive for their own benefit (self-consumption).

Another important result is that at least six operators representing public institution and administration (CRDA, ODS, DP), research institution (IO, IRA) and CBO's (SMSA) can ally to the achievement of the objectives of improving quality of olives and olive oil (QUALT) and so- cial innovation in olive value chain (INNOV). The strong power of IO and CRDA can help to the achievement of these consensual objectives.

Oddly, the "production" objective does not seem to correspond with any operator. This could be explained by the priority given to the other objectives by the operators of the OVC, as consequence of an unstable olive production (climate constraints, water resources scarcity) and of many other factors (land fragmentation, storage and handling difficulties, low public and private investments in productive infrastructure, low crushing capacity of mills, marketing difficulties and absence of skilled labourer).

This finding serves to categorize the objectives to be negotiated together at the conclusion of alliances or should be monitored in cases of conflict and their associated stakeholders. It permits to the formulation of strategic recommendations and key challenges about the OVC sustainability.

\section{Discussion: Towards an innovative olive value chain in Medenine}

In this work, we consider the promotion of the olive oil value chains in Medenine is a complex challenge that requires a holistic and comprehensive approach. This approach involves various sectors (private, public, community, etc.) in the framework of inclusive development based on a pro-poor approach that values and incorporates the contributions of the main stakeholders involved in OVC. The richness and complexity of stakeholder's relationships clarified some management aspects that can lead to the improvement of OVC in Medenine.

Results from the analysis of relationships between these stakeholders reveals the need that several actions should be considered to improve the sustainability performance of the OVC. In addition, such empirical findings claims that balance of power is most favourable for IO, UTAP and $\mathrm{ONH}$ (they are the dominant operators according to the analysis and they exert a strong influence on others without being strongly influenced), we have to rely on them for lobbying other operators such as EC, ODS and CRDA in order to revise the favourable positions to the 
objectives (innovation, quality, inclusive development, sustainability and extension). These objectives should be negotiated and treated together because each stakeholder can be either in favour or opposed to these objectives. The analysis confirms that all stakeholders can ally to the achievement of these objectives.

In addition, managers should try to find ways and actions (financial autonomy, capacity building, etc.) to improve the balance of power of the GDAs, SMSA and GIC since they are completely dominated. Finally, we should not forget the need to achieve all objectives for improving communication, coordination, cooperation and collaboration between all operators, in a context of continuous learning, in order to enhance the olive sector governance. This continuous learning, jointly undertaken by main stakeholders involved in OVC, enhances the role and the recommended relation powers and collaboration between these stakeholders, and promotes the inclusion of the already marginalized rural communities' for whom olive oil is the major source of income.

Similar results were found in Cañada and Vázquez (2005) in Spain. This study reported that enhancing relationships between the potential OVC stakeholders is a major action to promote olive sector and livelihoods through the quality certification of origin olive oil and the innovation of the local agro-food systems in Spain.

This work also strives to shed light on social innovation and governance in relation to the bio-economy and its role in sustainable rural development. This is with the aim to "find solutions which will make positive changes to local rural society, economy and environment, using olive sub-products more efficiently" and "contribute to securing sufficient supplies of bio-based products". The work includes renewable products and services from OVC (Schmid et al., 2012).

Social innovation is thus, in this view, a process of empowering disadvantaged groups so that their economic, social, and environmental conditions can change for the better. It is therefore intimately linked to the concepts of inclusiveness and to Elkington's (1997) concept of the "triple bottom line" of economic, social, and environmental impacts. Indeed, in this work, we considered also that the inclusive development of the OVC in Medenine, have to be accompanied by social learning and innovation in the framework of an innovation platform.

The overall objective was to analyze the role of different forms of social innovation in creating a sustainable bio-economy which maintains and creates economic growth, provides jobs and business opportunities (new activities, industries, employment), and contributes to the objective of sustainable development of studied rural area.

In this framework, findings suggest that the improvement of production systems, livelihoods' resilience and economic performance of the olive sector in Medenine can be realized by the management of the actual olive value chain in a more innovative, sustainable, efficient and integrated manner (Figure 6).

This innovative OVC will offers a tailored and systematic approach to better manage the sector of olive oil from production to market and contribute to create new opportunities (new jobs created through the creation of new institutions such as collection centre (cooperative), packaging and labelling unit, sub-products transformation unit), new products (olive sub-products) and new markets. Furthermore, it has the advantage to realize a better effectiveness of the role and functioning of the local institutions, policy makers, farmers, local actors, research, etc., around social innovations. Many other regions in which the bio-economy becomes much more important as a contributor to rural development in future, such as the production of biogas from olive sub-products in Italy and Spain, the forest based bio-energy (bio-fuel) in Slovenia, Norway, Finland and Russia. Many international research projects have also carried out important studies on social innovation and bio-economy, such as the "TRIBORN" project on "grounded innovation in bio-energy" in Norway, Sweden, Finland and Italy (Bryden and Gezelius, 2017), and the EU FW6 TOP-MARD project on multifunctional agriculture and territorial development (Bryden et al., 2006).

This innovative OVC is designed in the framework of the learning alliance processes which combine the efforts of stakeholders to success this new opportunity. The learning alli- 
Figure 6 - Innovative olive oil value chain (IOVC) in Medenine Governorate.

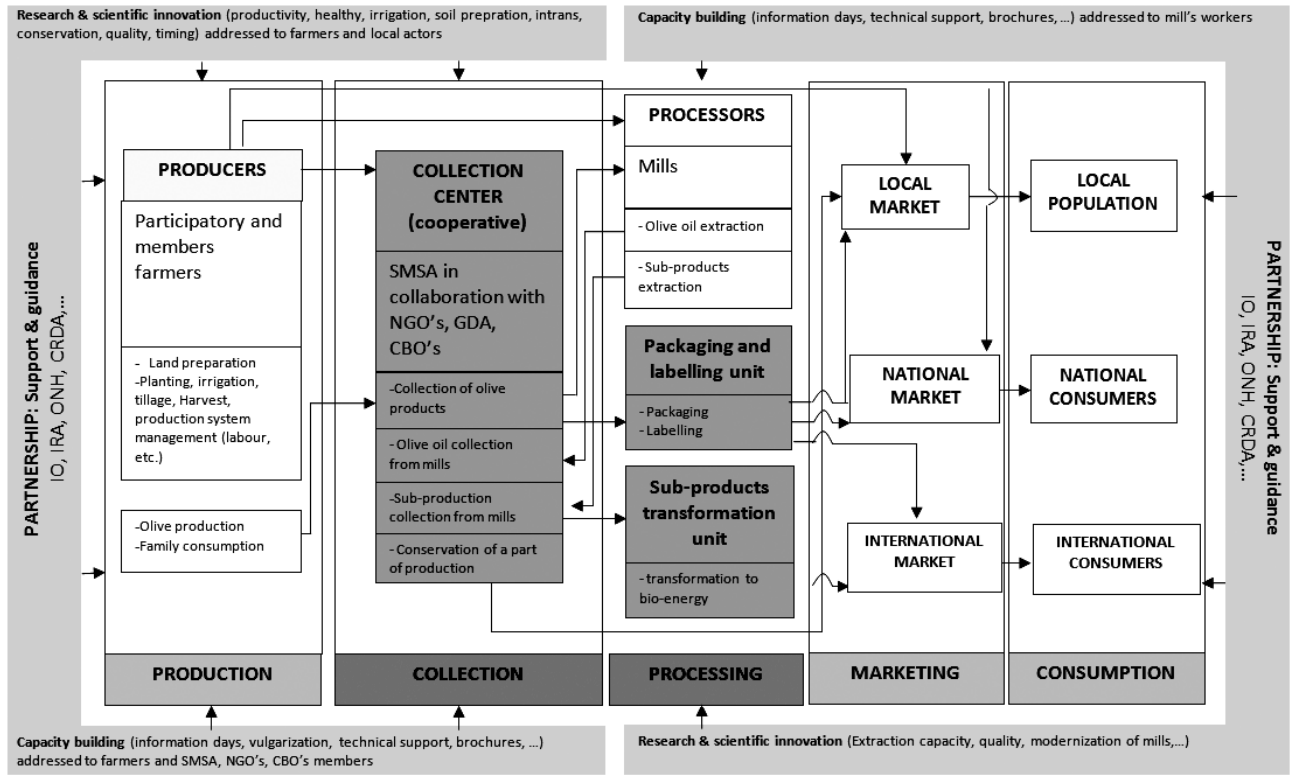

Source: own elaboration, 2019.

ance processes which have been carried out with the involvement of main stakeholders in OVC, within the different workshops, have contributed to a common agreement to focus the process of innovative OVC design in Medenine. This agreement has taken advantage from the local dynamic of multi-stakeholders in the region. In fact, there are several NGO's, CBO's, women and youth organisations which are very active. These local organisations have expressed a real interest and commitment to build a strong partnership within an innovative process based on social innovation and effective governance. This is by 1) enhancing private sector engagement in the innovation processes (implementation and involvement of existing institutions with better management, governance, participation, efficiency, etc., but also new specific institutions, policies, strategies and approaches to handle the bio-economy issues); 2) enhancing civil sector engagement in the innovation processes; 3) im- plementation of new and effective strategies by government related to improvement of the actual value chain and valorisation of bio-resources (in Tunisia there is a strategy of olive sector development, but not for valorisation of sub-products to bio-energy for example); and 4) by reorganizing the relations between government, civil sector and private sector (in term of facilities, implementation of new and effective strategies, legislations, better management, organization, confidence, cooperation, partnerships, etc.).

The new partnership, which can be implemented around the innovative OVC, could be supported and guided by several local and regional institutions and organizations, such as IRA, IO, ONH, APEX (national agency for export promoting). These latter will support all the innovative OVC processes (production, collection, processing, packaging, marketing) by innovative researches and scientific results, but also by capacity building, technical supports, etc. 
The objective is to relay a good and participative governance and management of the institutional framework to support not only the development of the OVC, but also to empower the economic and social conditions of disadvantage operators in the OVC.

To enhance OVC performance in Medenine Governorate, the initiative would be the creation of a new collection centre (cooperative) leaded by SMSA which plays the role of collection of olive products, management of products (diffusion to mills, conservation, etc.). It has also the role of diffusion of products to new packaging and labelling units, and sub-products of olives (Olive cake) to new transformation units. These three new units will be created in the framework of innovative OVC. The farmers (OG) could also benefit from some facilities provided by the SMSA (small credits, training, etc.) and the other support stakeholders (research institutes, administrations, etc.). The SMSA, with its new favourable balance of power, could play an active role to facilitate a local alliance process with the contribution of local NGOs and CBOs.

This innovative OVC is based on strengths and opportunities related to olive sector, such as the specificity of the local olive product. The Zarrazi variety in Beni Khedache (Medenine) for example presents a high quality of olive oil, a great adaptation capacity to drought and the specificity of Djebel and biologic product. This specificity can be valorised by creating a label for the olive oil of Beni Khedache, as the case. In Spain for example, "Hacienda Ortigosa" is one of the best labelled extra virgin olive oil in Europe (Claessens, 2019). There is also a significant spatial concentration of a wide-spread network of olive farms, oil mills and marketing firms, inputs suppliers, concentric diversification businesses, companies using olive by-products and local institutions related to olive oil and rural development, associations for integrated pest management, integrated production associations, networks and associations of organic farmers, rural development groups, etc. These local olive oil systems not only produce commercial goods and add value to local chains but are also characterised by their production of public goods (Sanz-Cañada et al., 2015).
The promotion of the olive sector must also involve a multitude of actions, changes and strategies to improve the performance, competitiveness and sustainability of olive farms in the region. We can advance the idea of intensification of olive cultivation in the Governorate through increasing the density of olive trees, improving fertilization and maintenance, but also the qualification of workers (services providers) and the use of new technologies for harvesting, storage and processing to improve the productivity and quality of olive oil, especially for small farms.

We can also cite the example of a land consolidation strategy that has already been implemented in some regions of Medenine Governorate for at least a decade, in order to limit the negative impacts of land fragmentation, and to improve access to agricultural credits for small farms. The consolidation of the processing industry in the Governorate is also of great importance by installation of modern mills in order to meet the spatial distribution and the processing needs of olive production (in term of capacity and quality). Then, spatial study of the sector is necessary to meet this objective and especially the competitiveness of small farms in the OVC.

The innovative OVC is based also on valorisation of olive sub-products. In fact, the objective behind the creation of a new processing unit of olives' sub-products is to find innovative ways and new opportunities. It consists on a transition towards an optimal/more efficient use of the renewable biological resources, and a shift to an economy based on local or biological resources residues, sub-products. We particularly focus on pomace and wood which are used as bio-energy for heating for long time ago. Our choice was based on the fact that the Governorate of Medenine has a great potential of olive trees (4 million trees), 200000 tons/year of wood derived from olive trees, and about 40000 tons/year of pomace (ODS, 2017). The olive pomace is a sub-product of the extraction process of the olive oil composed of skins, residues of the pulp and fragments of nuclei. It is a very appropriate additive for the units of gasification for the production of bio-gaz. In fact, the pure pomace is a very good fuel, easy to use 
and with a high calorific value, which can be used as substitute of wood heating in granules for boilers and stoves. It is used in the oil mills to heat the water used in the phase-mixing or marketed as a substitute for wood pellets. Then, the main issue of bio-transformation of pomace in the framework of the innovative OVC is to produce bio-energy, with fewer inputs, less environmental impact and reduced greenhouse gas emissions: low carbon economy. This has been demonstrated in many other cases all over the world, such as the successful experience of bio-transformation of agro-industrial residues for the generation of electricity in Spain, where olive mill and wood processing residues have the largest energy potentials. Three Andalusian provinces exhibit the highest potential from olive mill residues (Jaén: 91,8 Mega Watt electrical (MWe); Córdoba: $50 \mathrm{MWe}$; and Sevilla: $23,8 \mathrm{MWe}$ ), with a respectively net present value (NPV) of $45 \mathrm{M} €, 33 \mathrm{M} €$ and $30 \mathrm{M} €$ (Gómez et al., 2010). There is also the example of the ecological modernisation and discourses on rural non-wood bio-energy production and wood fuels for heating purposes in Finland (Huttunen, 2009). There is also a successful experience of the bio-transformation of olive leaves for pharmacological activities in some European and North African countries. This experience shows that oleuropein (antioxidant and phenolic component) (up to 6-9\% of dry matter in the leaves) possesses a wide range of pharmacological and health-promoting properties including antiarrhythmic, spasmolytic, immune stimulant, cardioprotective, hypotensive, antioxidant and anti-inflammatory effects (Ben Salem et al., 2014).

In addition, to reduce the unbalanced profit margin distribution in the OVC, we should fade the role of traders (TR) and encourage farmers (OG) to buy their products to SMSA, who takes the responsibility to ensure new processing, packaging and marketing operations. This is in order to ensure inclusive development and effective involvement of marginalized rural areas in an effective pro-poor OVC (Sanz-Cañada et al., 2015). Finally, it is important to highlight a certain number of limitations, notably concerning the gathering of required input. Stakehold- ers are naturally reticent about revealing their strategic projects and their means of external action. This needs additional effort and expertise from focus groups facilitators to be able to extract relevant and accurate information in order to undertake a thorough analysis of social innovations influencing bio-based value chains. In fact, the FGDs are not only a tool for research but also an objective per se, as they can provide the means for co-learning and knowledge exchange as well as for development of further social innovations in the bio-economy and rural development.

The proposed new practices and inclusive approaches can be exported to other regions of Tunisia (Châal for example in the centre, which has a great production potential of olives), but also provide, in term of perspectives, a starting point for comparative research and analysis to other developing and developed countries, in terms of applied experiences in social innovation and local development and participatory methods of research, policy advice and engagement (actor-networks involved in social innovation, collective learning arrangements and institutional capacity building processes, outcomes of social innovation, new production/increased value creation, and employment, distribution of value created and other inclusive welfare indicators, environmental sustainability (impacts on climate gas emissions; impacts on biodiversity; impacts on other ecosystem services; sustaining biomass capacity, etc.)).

The analysis of learning processes in different case studies can thus be a tool to analyze why regions with similar initial conditions may display diverging paths; to compare how various collective learning processes differ between the regions, and to compare forms of innovation and governance for the new bio-economy under different agro-ecological contexts.

Additional investigations and studies could be effective to deepen the OVC analysis in different contexts. These studies may use public data, legal and policy documents, literature and interviews to provide comparable data using a common analytical grid on the institutional (governance and policy) framework around the bio-economy, with a specific 
focus on its (positive or negative) influence on the practice of social innovation in rural development and factors fostering its development. These studies may also provide data on the general economic and geographical influences upon and political importance of the bio-economy for rural areas in each region. In addition, they may provide information on national bio-economy strategies, the processes and actors involved in their creation, and their recognition of the role of social innovations and links to rural development.

\section{Concluding remarks and practical recommendations}

This research has shown the importance and challenges of olive sector in the Governorate of Medenine. The main operators of the olive oil value chain have been identified, as well as their interactions, influences, and their profit margins. This work also proposed recommendations and strategic pathways for enhancing sustainability of the olive sector in Medenine.

We tested the proof of concept regarding learning alliances in south-eastern Tunisia, with a primary aim to uncover approaches for providing rural communities and stakeholders with a wider set of avenues for expressing voice and ability to contribute to promotion of olive sector in the framework of inclusive development.

Thus, the development and adoption of contextually relevant technologies and innovations are more likely to be successful when there is a process of continuous learning, jointly undertaken by research organizations, farmers, marketing agents, donors, NGO's, financial service providers, policy makers, and relevant civil society actors. This process has to consider the influences and relationships between all stakeholders involved in OVC and as well as their strategic positions towards objectives of sustainable OVC.

There were initial concerns that this process of joint learning was likely to face a significant number of obstacles, and largely related to political sensitivity and contemporary insurrection; however, individual farmers, civil society, and local government participants cast aside any concern, and in large measure endorsed the approach as one of significant value and need.

\section{Acknowledgements}

This paper was elaborated as part of a research collaboration agreement between the International Center for Agricultural Research in the Dry Areas (ICARDA) and IRA, undertaken within the Consortium Research Program (CRP). Authors would like to acknowledge ICARDA, IRA and all local and regional partners for their valuable collaboration.

\section{References}

Ahmed C.B., Rouina B.B., Boukhris M., 2008. Olive trees and water deficit: photosynthesis, stomatal behavior and fruit development. Revue des régions arides, 21:517-520.

Aube T., 1994. Analyse concurrentielle des filières maraîchères dans quatre pays : Sénégal, Maroc, Kenya, Thaïlande. Paris: CIRAD/FLHOR.

Ben Salem M., Affes H., Ksouda K., Sahnoun Z., Zeghal K.M., Hammami S., 2014. Pharmacological activities of Olea europaea leaves. Journal of food processing and preservation, 39(6): 3128-3136.

Bryden J., Gezelius S.S., 2017. Innovation as if people mattered: the ethics of innovation for sustainable development. Innovation and Development, 7(1): 101118. DOI: 10.1080/2157930X.2017.1281208.

Bryden J., Refsgaard K., Johnson T.G., 2006. Towards a policy model of multifunctional agriculture and rural development (top-mard). International Conference on "The diversity of rural areas in the enlarged EU: Characterisation, typology and modeling", Sevilla, December 2006.

Cañada J.S., Vázquez A.M., 2005. Quality certification, institutions and innovation in local agro-food systems: protected designations of origin of olive oil in Spain. Journal of Rural Studies, 21(4): 475-486.

Claessens C., 2019. La meilleure huile d'olive. www. selectos.eu/meilleures-huiles-olive/.

Elkington J., 1997. Cannibals with Forks: The Triple Bottom Line of 21st Century Business. Oxford: Capstone Publishing.

Elmsalmi M., Hachicha W., 2014, Risks mitigation strategies according to the supply actors' objectives through MACTOR method. In: Proceeding of 2014 International Conference on Advanced Logistics and Transport (ICALT), pp. 362-367. 
European Commission, 2013. Annual activity report 2013. Regional and urban policy. https://ec.europa. eu/info/publications/annual-activity-report-2013-regional-and-urban-policy.

Fleskens L., Stroosnijder L., Ouessar M., De Graaff J., 2005. Evaluation of the on-site impact of water harvesting in southern Tunisia. Journal of Arid Environments, 62(4), 613-630.

Gildemacher P.R., Wongtschowski M., 2015. Catalysing innovation: from theory to action. KIT Working Papers 2015: 1. https://www.kit.nl/working-paperseries-2015-1-catalysing-innovation-from-theory -to-action/.

Godet M., 1979. The crisis in forecasting and the emergence of the "prospective" approach: with case studies in energy and air transport. Pergamon Press. https://scholar.google.com/scholar?hl= fr\&as_sdt $=0 \% 2 \mathrm{C} 5 \& \mathrm{q}=\mathrm{M}+$ Godet $+-+1979+-+$ Pergamon+Press\&btnG $=$.

Godet M., 1991. Actors' moves and strategies: the MACTOR method - An Air Transport Case Study. Futures, 23(6): 605-622.

Godet M., Durance Ph., 2011. Strategic Foresight for Corporate and Regional Development. DUNOD UNESCO - Fondation Prospective et Innovation.

Gómez A., Zubizarreta J., Rodrigues M., Dopazo C., Fueyo N., 2010. An estimation of the energy potential of agro-industrial residues in Spain. Resources, Conservation and Recycling, 54(11): 972-984.

Hachani A., Ouessar M., Zerrim A., 2015. Contribution to the study of water stress on olive growing under the effect of climate change behind the soil and water conservation techniques in South East of Tunisia. In: Proceedings EGU General Assembly 2015, Geophysical Research Abstracts, 17, p. 336.

Homann-Kee Tui S., Adewale A., Lundy M., Tucker J., Birachi E.A., Schut M., Klerkx L., Ballantyne P., Duncan A., Cadilhon J., Mundy P., Ombati A., 2013. What are innovation platforms? Innovation platforms practice brief 1 . International Livestock Research Institute, CGIAR Challenge Program on Water and Food, pp. 1-7.

Howaldt J., Schwarz M., Henning K., Hees F., 2010. Social Innovation: Concepts, Research Fields and International Trends. In: Studies for innovation in a modern working environment, vol. 5, International monitoring. Aachen: IMA/ZLW, IfU.

Huttunen S., 2009. Ecological modernisation and discourses on rural non-wood bioenergy production in Finland from 1980 to 2005. Journal of Rural Studies, 25(2): 239-247.

INS, 2015. Institut National de la Statistique, Tunis. www.ins.tn (accessed on June 10 ${ }^{\text {th }} 2018$ ).
Jaouad M., Gaillard C., 2017. Approche méthodologique pour l'élaboration d'une typologie des exploitations agricoles en Tunisie. Projet TCP/ INT/3504D : Renforcement des capacités de suivi de la diversité et des transformations des exploitations agricoles pour améliorer la formulation de politiques et le conseil agricole, MARHP/DGEDA/ FAO/WAW.

Karray B., Abichou M., 2007. Fonctionnement, performances et devenir des exploitations oléicoles privées à Médenine (Tunisie). Tropicultura, 25(1): 26-30.

Karray B., Kanoun F., 2013. Forces, Faiblesses, Opportunités et Menaces de la filière oléicole en Tunisie. New Medit, 12(4): 35-45.

Nederlof S., Wongtschowski M., Van der Lee F. (eds), 2011. Putting heads together. Agricultural innovation platforms in practice. Bulletin 396. Amsterdam: KIT Publishers.

ODS, 2017. Gouvernorat de Medenine en chiffres.

Oxfam, 2018. Inclusive development: ensuring benefits for all. Briefing note. https://www.oxfam.org/sites/ www.oxfam.org/files/inclusive_development.pdf.

Porter M.E., 1985. Competitive advantage: creating and sustaining superior performance. New York: Free Press.

Sanz-Cañada J., Barneo Alcántara M., García-Brenes M.D., 2015. Value chain and typicity analysis in Jaén Mountain olive oil, Spain. New Medit, 14(3): 50-60.

Schmid O., Padel S., Levidow L., 2012. The Bio-Economy Concept and Knowledge Base in a Public Goods and Farmer Perspective. Bio-based and Applied Economics Journal, 1: 47-63.

Sghaier M., 2017. Vision et approche de mise en place d'un observatoire des exploitations agricoles en Tunisie. Projet TCP/INT/3504D : Renforcement des capacités de suivi de la diversité et des transformations des exploitations agricoles pour améliorer la formulation de politiques et le conseil agricole. MARHP/DGEDA/FAO/WAW.

Sghaier M., Abdeladhim A.M., Tonneau J.-P., Ounalli N., Jeder H., Bonin M., 2012. Land degradation in the arid Jeffara Region, Tunisia. In: McNeill D., Nesheim I., Brouwer F. (eds.), Land Use Policies for Sustainable Development: Exploring Integrated Assessment Approaches. Cheltenham: Edward Elgar Publishing, pp. 89-110.

Stamm A., Von Drachenfels C., 2011. Value Chain Development: Approaches and Activities by Seven UN Agencies and Opportunities for Interagency Cooperation. Geneva, Switzerland: International Labour Office. www.fao.org/3/a-an890e.pdf.

Swaans K., Boogaard B., Bendapudi R., Taye H., Hendrickx S., Klerkx L., 2014. Operationalizing inclu- 
sive innovation: Lessons from innovation platforms in livestock value chains in India and Mozambique. Innovation and Development, 4(2): 239-257.

Triomphe B., Rajalahti R., 2013. From concept to emerging practice: What does an innovation system perspective bring to agricultural and rural development? In: Coudel E., Devautour H., Soulard C.T., Faure G., Hubert B. (eds.), Renewing innovation systems in agriculture and food. How to go towards more sustainability? Wageningen: Wageningen Academic Publishers, pp. 57-76. https://doi.org/10.3920/978-90-8686-768-4.

World Bank, 2007. The World Bank Annual Report 2007. Washington, DC: World Bank. https://openknowledge.worldbank.org/handle/10986/7534.
Yahya R., 2017. Analyse du secteur oléicole dans le gouvernorat de Médenine-Cas de bassin versant Oum Zessar. Mastère de recherche INAT/IRA "Aridoculture et lutte contre la désertification".

\section{Web Links}

https://www.weforum.org/reports/the-inclusive-development-index-2018) (accessed on August 30 $0^{\text {th }}$ 2018).

http://en.laprospective.fr/methods-of-prospective/softwares/60-mactor.html (accessed on September 14 $4^{\text {th }}$ 2018).

https://www.weforum.org/reports/the-inclusive-development-index-2018 (accessed on January $28^{\text {th }}$ 2019). 